\title{
等分布鉛直荷重を受ける円筒ラチス屋根の部材断面算定法 \\ A PROPORTIONING METHOD FOR MEMBERS \\ OF CYLINDRICAL LATTICED ROOFS UNDER UNIFORM VERTICAL LOADING
}

\author{
加藤 史 郎*, 仁保 裕**, 金 鍾 敏*** \\ Shiro KATO, Yutaka NIHO and Jong-Min KIM
}

\begin{abstract}
This paper presents a proportioning method for constitutive members of cylindrical latticed roofs under uniform vertical loading. The method can be applied to design member sections of long roofs as cylindrical shells. Member axial forces and bending moments for design are first obtained based on FEM linear elastic analysis together with FEM linear buckling analysis for estimating the generalized equivalent slenderness. And, second, the bending moments are amplified considering the interaction between axial force and bending moment. Member elasto-plastic buckling strength is defined based on the theory of column buckling strength curves using the generalized slenderness. To define the buckling strength of members parallel to the generatrix as well as along arch direction, buckling analysis for not only uniform lateral but also axial loading are applied. Finally, a series of FEM elasto-plastic analysis is conducted for cylindrical latticed roofs, which are provided based on the present proportioning method, and a confirmation about availability of the present proportioning method is firmly given.
\end{abstract}

\section{Keywords : cylindrical latticed roof, uniform vertical loading, proportioning method for members 円筒ラチス屋根, 等分布鉛直荷重, 部材断面算定}

\section{1. はじめに}

単層ラチスシェルは面内剛性に比して面外剛性が小さく, 座屈前の幾何 学的非線形性，および材料の降伏が座屈性状に大きな影響を及ぼすことが 知られている ${ }^{1-6)}$.このため, 実設計の初期段階では幾何非線形性や材料 の降伏強度を考虑しつつシェル形状，および，部材断面を定める必要があ る.これまで，ラチスドームを対象とした形状最適化手法(例え゙゙ 7-99や部材断

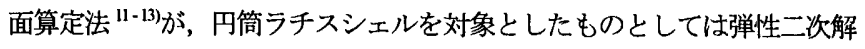

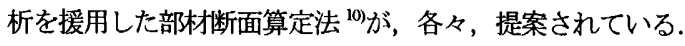

円筒ラチスシェルの力学的挙動は，そのラチスシェルの境界条件に影響 される ${ }^{2-9}$. 図 2 に示される周辺単純支持条件のような場合, 母線長が円 弧長よりも短い円筒ラチスシェル（以下, ショートシェル) では, ラチス シェルの母線軸に斜めに交わる部材（以下，斜め材）に圧縮力が生じ，母 線軸に平行な部材（以下，母線方向材）の軸力は比較的小 さい 1, 2). 一方，母線長が円弧長よりも長い円筒ラチスシェル（以下，口 ングシェル）では, 大きな圧縮力が斜め材のみならず, 中央部の母線方向 材にも発生する.

境界条件として周辺単純支持を仮定した円筒ラチスシェルの部材断面算 定では, 上記の特徴を踏まえて断面算定用の弾塑性座屈応力度を定めるこ とが必要となる. 文献 10)に示される部材断面算定法は, ショートシェル の弹塑性座屈挙動を分析した文献 1)および 14)に示されている弾塑性座屈
态力度を用いており，斜め材の座屈応力度のみを定める. 従って，この部 材断面算定法を，母線方向材にも大きな圧縮力が発生するロングシェルの 部材断面算定に用いることは適切ではない．

ロングシェルの部材断面算定を行う際には，斜め材のみならず，母線方 向材についても断面算定用の弾塑性座屈応力度を定めることが求められる. 母線方向材の座屈応力度を定めるには，母線方向材に発生する圧縮力がラ チスシェルの座屈荷重に強く影響すると思われる状況を参照するのが望ま しい，つまり，母線方向材に大きな圧縮力が発生し，斜め材には殆ど軸力 が発生しない状況を参照して母線方向材の弾塑性座屈応力度を定めるのが よいと考えられる. また，周辺単純支持された円筒ラチスシェルでは，境 界縁付近の部材に比較的大きい曲げモーメントが生ずる ${ }^{1}$. 従って, 特定 部材の弾塑性座屈応力度を定める際には, なるべく曲げモーメントの発生 が少ない状況を基淮として弾塑性座屈応力度を定め, 一方, 断面算定で曲 げモーメントの影響を考慮するのがよいと考えられる.

そこで，本報では，円筒ラチスシェルを対象とし，斜め材と母線方向材 を別個に扱い，それぞれについて圧縮材の中で降伏軸力に対する軸力の比 が最大となる部材（以下，特定部材）を選び出し，この部材の弾塑性座屈 灾力度を用いて部材断面を求める方法について議論を行う。

なお，母線方向材の座屈応力度は，円筒ラチスシェルが母線方向に軸圧 縮される (図 4 参照) と仮定して行われた座屈解析結果に基づいて定める.

\footnotetext{
* 豊橋技術科学大学建設工学系 教授. 工博

** 愛㛖大学工学部琀境建設工学科 助手・修士 (工学)

*** 豊橋技術科学·大学 外国人研究者・博士 (工学)
}

Prof., Dept. of Architecture and Civil Engineering, Toyohashi University of Technology, Dr. Eng.

Research Assoc., Dept. of Civil and Environmental Engineering, Faculty of Engineering, Ehime University, M. Eng.

Visiting Researcher, Toyohashi University of Technology, Dr. Eng. 

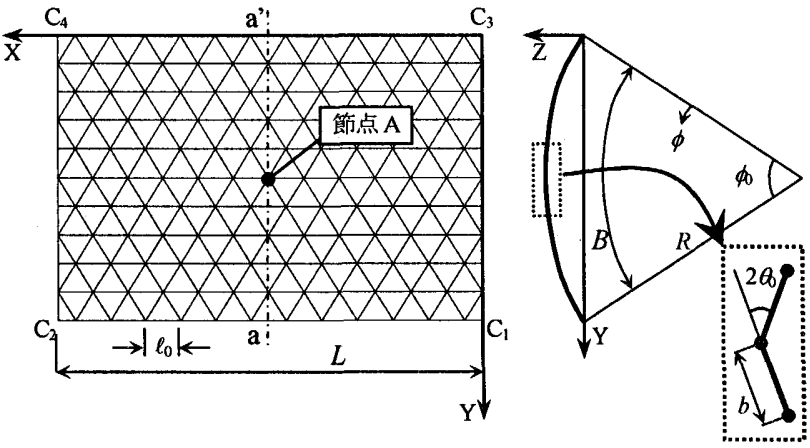

図 1 円筒ラチスシェル

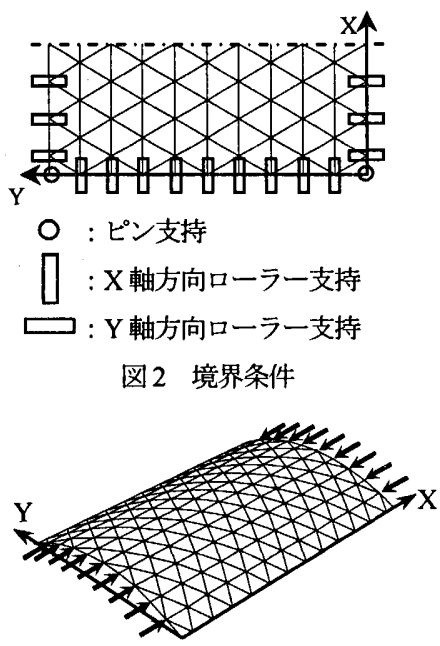

1 節点に $P_{h 0}(=9.8 \mathrm{kN})$ ずつ載荷する 図 4 軸圧縮荷重

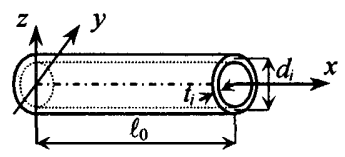

図 6 想定する部材

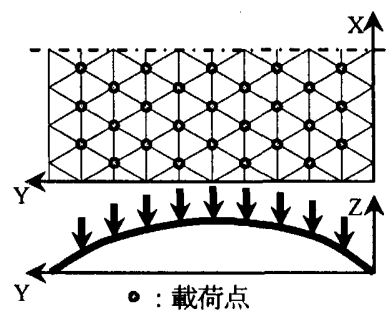

図3荷重条件

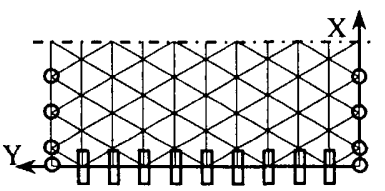

○ : ピン支持

］：X軸方向ローラー支持

図 5 ピン支持

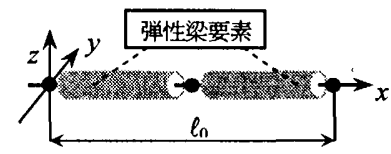

図 7 計算における部材モデル
これは，軸圧縮される円筒ラチスシェルに関して，母線方向材に大きな圧 縮力が発生し，斜め材に殆ど軸力が発生せず，かつ，曲げが殆ど発生しな いためである ${ }^{20)}$. 一方, 斜め材の弾塑性座屈応力度を定めるために, 母線 縁に沿ってピン支持された円筒ラチスシェル(図 5 参照)に等分布鉛直荷重 (図 3 参照)が載荷される場合を想定する. 座屈前はアーチ的な挙動が保た れ, かつ, 曲げモーメントの発生が少ないと仮定し, 斜め材の座屈応力度 を定める.

これらの座屈応力度を援用して断面算定された円筒ラチスシェルの最大 而力を弾塑性座屈解析から求め, 算定法の妥当性を検郡する.

\section{FEM 線形座屈解析を援用した部材断面算定法}

FEM 線形座屈解析を援用した円筒ラチスシェルの部材断面算定法につ いて説明する. 本算定法は，三角形格子のラチスドームに適用される部材 断面算定法 ${ }^{13}$ に淮拠する. 図 8 に本算定法の全体の流れを示すが, ここで は, 部材の弾塑性座屈応力度の定義に焦点をあて記述を行う.

本算定法は，正三角形格子により構成される円筒ラチスシェルが， $\mathrm{z}$ 方 向下向きの等分布荷重を受ける場合 (図 3 参照) を想定する. 部材は円管 断面を持つ鋼管 (ヤング俰数 $E=20,580 \mathrm{kN} / \mathrm{cm}^{2}$, 降伏忍力度 $\sigma_{p}=23.5 \mathrm{kN} / \mathrm{cm}^{2}$ )
であり(図 6 参照)，かつ，両端で節点に剛接合されているとする．なお， 部材断面算定中の数値計算において十分な精度を確保するために，部材は 2 つの弾性梁要素から構成されるモデルに置き換える(図 7). なお，部材 $i$ の直径 $d_{i}$, 断面積 $A_{i}$, 断面二次モーメント $I_{i}$, 降伏軸力 $N_{p i}$ ，および，全塑 性モーメント $M_{p i}$ は次式により計算する.

$d_{i}=2 \sqrt{2}\left(\ell_{0} / \lambda_{0}\right), \quad A_{i}=\pi d_{i} t_{i}, I_{i}=\left(\pi d_{i}^{3} t_{i}\right) / 8, \quad N_{p i}=\sigma_{p} A_{i}, \quad M_{p i}=\sigma_{p} d_{i}^{2} t_{i}$

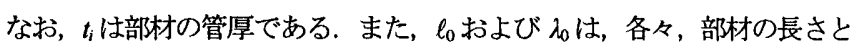
細長比である.

\section{1 断面算定に用いる部材の弾塑性座屈応力度の計算法}

\subsection{1 幾何非線形性の影響を考虑するための座屈荷重低减保数の仮定}

I. 軸圧縮される円筒ラチスシェルの座屈荷重低减俰数 $\alpha_{0}$ と $\lambda_{0} \theta_{0}$ の関係 ${ }^{15}$ を図9(1)（後述）に表す. ただし， $a_{0}=P_{\sigma r}^{\text {ela }} / P_{\sigma r}^{\text {in }}$ であり，かつ， $P_{\sigma}^{\text {in }}$ は FEM 線形座屈荷重, $P_{c}^{e l a}$ は FEM 非線形弾性座屈荷重である. 図 $9(1) に$ 示される $\lambda_{0} \theta_{0}$ と $\alpha_{0}$ の関係を, 部材細長比 $\lambda_{0}$ と部材半開角 $\theta_{0}$ を用いて式(2) で近似的に表し，母線方向材の断面算定に用いる座屈荷重低减俰数 $a_{g}$ と する.

$$
\alpha_{g}=\frac{1.2 \sqrt{\lambda_{0} \theta_{0}}}{\sqrt{\lambda_{0} \theta_{0}}+1.0}
$$

II. 鉛直等分布荷重を受けるピン支持された円筒ラチスシェル ${ }^{14)}$ の座屈荷 重低减係数 $\alpha_{0}$ と $\lambda_{0}$ の関係を図 9(2)に示寸。この結果に基づいて, 斜め材 の断面算定に用いる座屈荷重低㺂俰数を $\alpha_{d}$ とし, 次式で求める.

$$
\left.\begin{array}{ll}
a_{d}=0.65 & \left(\lambda_{0}<60\right) \\
\alpha_{d}=0.80 & \left(\lambda_{0} \geqq 60\right)
\end{array}\right\}
$$

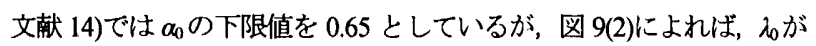
60 以上ならば， $\alpha_{0}$ の下限值はもう少し高めであるように見受けられる. そのため, 斜め材の断面算定用の座屈荷重低減係数 $\alpha_{d}$ を式(3)のように表 した. なお， $\lambda_{0}$ が 40 より大きく，かつ，60末满である範囲について， $a_{d}$ の值は図 9(2)から直接判断できないが，より安全側の值をとるように配

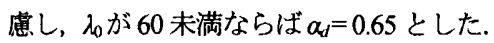

2.1.2 母線方向材の断面算定に用いる座屈応力度 $\sigma_{\mathrm{cgi}}$ の計算

I. 円弧縁上の節点にX軸方向の圧縮荷重 $P_{h 0}(=9.8 \mathrm{kN})$ を受ける円筒ラチ スシェル (図 4) について, FEM 線形弾性解析を行い部材 $i$ の軸力 $N_{h i}$

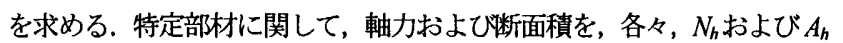
と表す.

II. 上記の解析で得られる軸力を用い, 線形座屈解析を行う。式(4)を解い て線形座屈固有值 $\lambda_{\text {og }}$ を求める. なお, 式(4)を解くと $\lambda_{\text {og }}$ は未知数の個数 と同じ数だけ求まるが, ここでは最小の固有值のみを扱う. 最小の固有

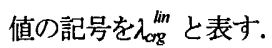

$$
\operatorname{det}\left|\left[\mathbf{K}_{\mathbf{E}}\right]+\lambda_{\text {agg }}\left[\mathbf{K}_{\mathbf{G}}\left(N_{h i)}\right)\right]\right|=0
$$

$\left[\mathbf{K}_{\mathbf{E}}\right]$ は線形弾性剛性マトリクス, $\left[\mathbf{K}_{\mathbf{G}}\left(N_{h i}\right)\right]$ は幾何㓮性マトリクスである. 次式により, 母線方向の特定部材の線形座屈応力度 $\sigma_{c \text { cr }}^{\text {lin }}$ を計算する.

$$
\sigma_{\text {crg }}^{\text {lin }}=\left(\lambda_{\text {crg }}^{\text {lin }} N_{h}\right) / A_{h}
$$

III. 次式により，母線方向の特定部材の弾性座屈応力度 $\sigma_{c g}^{e h}$ を計算する.

$$
\sigma_{\text {crg }}^{\text {ela }}=\alpha_{g} \sigma_{\text {crg }}^{\text {lin }}
$$




\section{START}

構造物の全体形状，境界条件の設定，形状初期不整の仮定
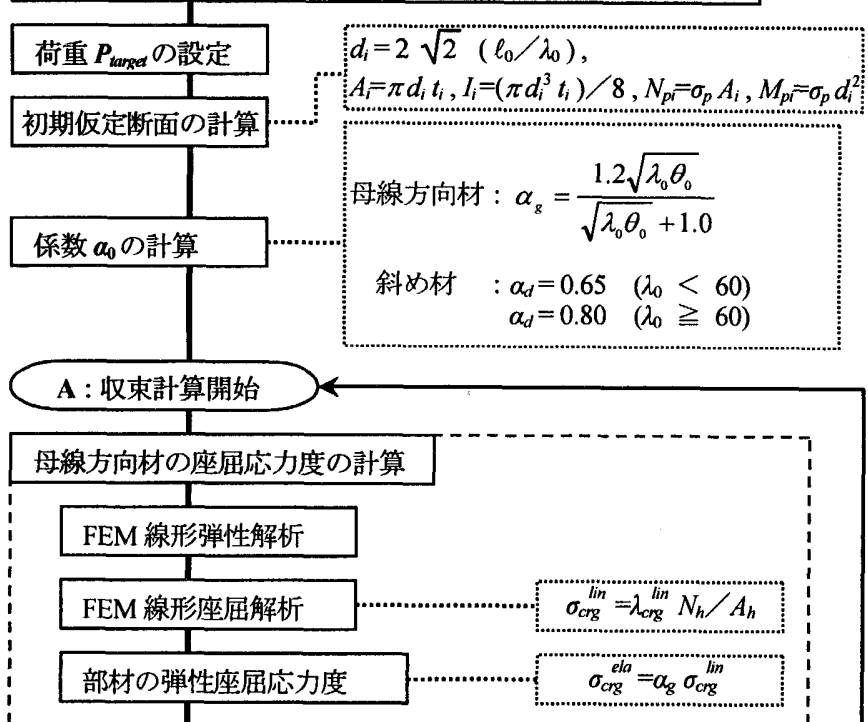

部材の弹塑性座屈态力度

(1) 正規化細長比 $\Lambda_{g i}$ の計算 $\Lambda_{g i}=\sqrt{\sigma_{p} / \sigma_{c g g}^{\text {ela }}}$

(2) 弹塑性座屈応力度の推定值の計算

$$
\begin{aligned}
& \sigma_{c z^{i}}^{\text {ett }}=\sigma_{p} \\
& \sigma_{c y^{\prime}}^{\text {enf }}=\sigma_{p}\left\{1-0.523\left(\Lambda_{g i}-0.5\right)^{2}\right\} \\
& \sigma_{c y^{\prime \prime}}^{\text {etit }}=\sigma_{p} /\left(\Lambda_{g^{\prime}}{ }^{2}\right) \\
& \left(\Lambda_{g^{\prime}}<0.5\right) \\
& \left.\left(0.5 \leq \Lambda_{g^{\prime}}<1 / \sqrt{0.8}\right)\right\} \\
& \left(\Lambda_{g i} \geq 1 / \sqrt{0.8}\right)
\end{aligned}
$$

(3) 断面算定用座屈忘力度の計算 $\sigma_{c g g i}=\sigma_{c r g i}^{E s} / f_{c} \quad\left(f_{c}=1.2\right)$

\section{斜め材の座屈応力度計算}

\section{FEM 線形弹性解析}

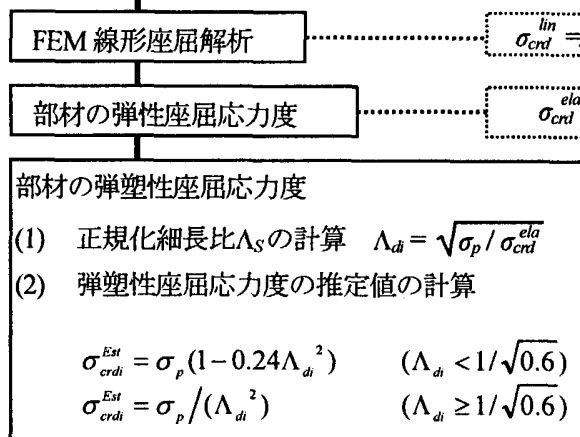

(3) 断面算定用座屈忘力度の計算 $\sigma_{c n i t}=\sigma_{c n t i}^{E t} / f_{c} \quad\left(f_{c}=1.2\right)$

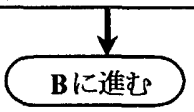

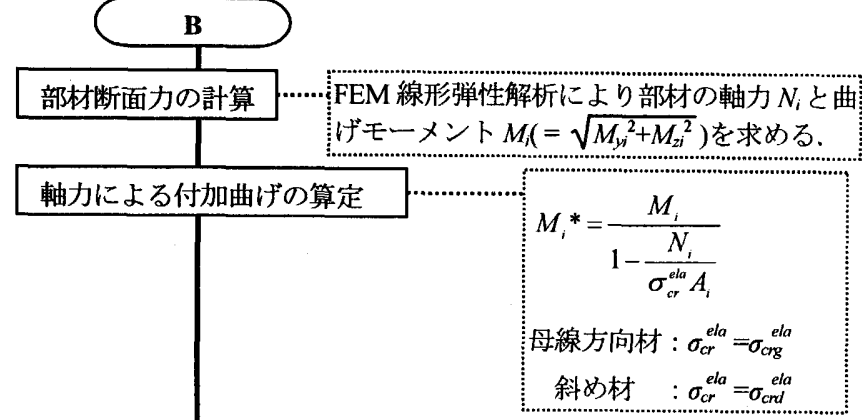

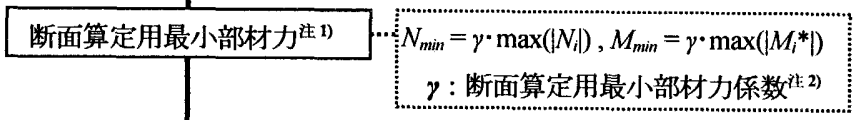

断面算定用部材力 $N_{d}=\max \left(N_{i}, N_{\min }\right), M_{d}=\max \left(M^{*}, M^{\prime}\right)$

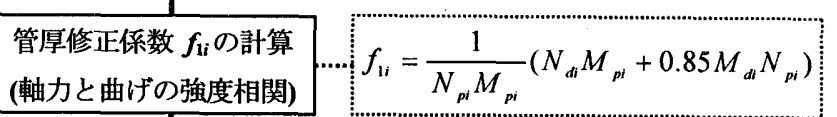
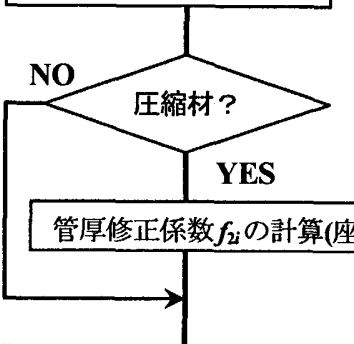

$f_{2 i}$ の計算(座屈の照査) $f_{2 i}=N_{d i} /\left(\sigma_{c r i} A_{p i}\right)$ 母線方向材 : $\sigma_{c r i}=\sigma_{c r g i}$ 斜め材 : $\sigma_{c r i}=\sigma_{c n t}$

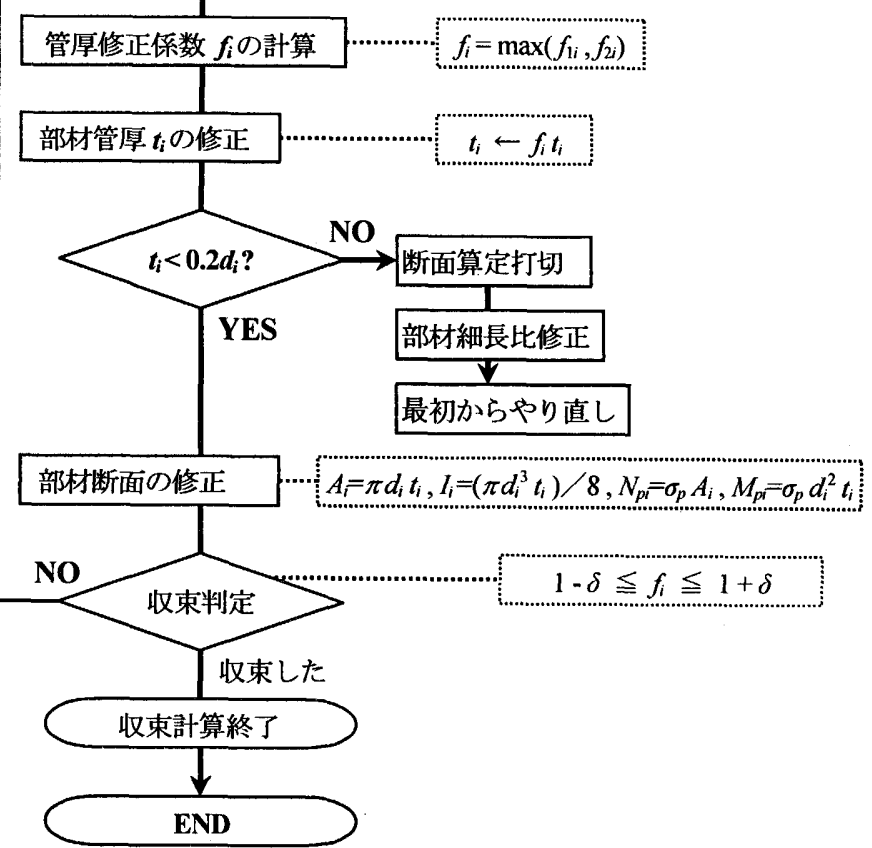

図 8 線形座屈解析を援用した円筒ラチスシェルの部材断面算定法の流れ図
IV. 母線方向材の断面算定に用いる弾塑性座屈応力度 $\sigma_{c g i}$ の計算

(i) 正規化細長比 $\Lambda_{g i}$ を次式(7)により計算する.

$$
\Lambda_{g i}=\sqrt{\frac{\sigma_{p}}{\sigma_{c r g}^{e l a}}}
$$

(ii) 図 10(1)は軸圧縮される円筒ラチスシェルの特定部材の正規化細長比 $\Lambda_{g i}$ と弾塑性座届軸力 $N_{c r}^{e p l}$ の関係 ${ }^{15)}$ を表す．なお, $\Lambda_{g i}$ は式(7)により計算
され，また， $\alpha_{g}$ の計算は式(2)による， $N_{c r}^{e p l}=\left(P_{c r}^{e p l} / P_{h 0}\right) N_{h}$ として計算さ れている.ただし， $P_{\text {cr }}^{e p}$ は FEM 弾塑性座屈荷重である. 図 10(1)を参照 し, 母線方向材の弾塑性座屈応力度の推定値 $\sigma_{\text {cgi }}^{E x}$ を式(8)により計算する.

$$
\begin{aligned}
& \sigma_{c r g i}^{E s t}=\sigma_{p} \\
& \sigma_{\text {crgi }}^{E s t}=\sigma_{p}\left\{1-0.523\left(\Lambda_{g i}-0.5\right)^{2}\right\} \\
& \left(\Lambda_{g i}<0.5\right) \\
& \sigma_{c r g i}^{E s t}=\sigma_{p} / \Lambda_{g i}{ }^{2} \\
& \left(0.5 \leq \Lambda_{g^{\prime}}<1 / \sqrt{0.8}\right) \\
& \left(\Lambda_{g i} \geq 1 / \sqrt{0.8}\right)
\end{aligned}
$$


(iii) 母線方向材の断面算定に用いる座屈応力度 $\sigma_{c \text { cki }}$ を計算する.

$$
\sigma_{c g i}=\sigma_{c g i j}^{E s} / f_{c}
$$

$f_{c}$ は部材の元たわみ，残留応力などを考慮するための係数であり個々の ラチスシェルの部材の製作の精度などを勘案して定められるべきもので ある. 本研究では, 鋼構造限界状態設計指針・同解説 ${ }^{19}$ の圧縮材の設計 における耐力倸数を参照し, $f_{c}=1.2$ とした.

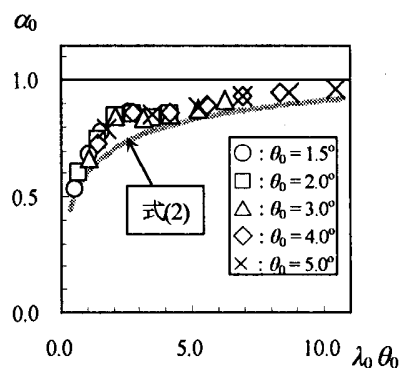

(1)軸圧縮される円筒ラチス シェル ${ }^{15}$

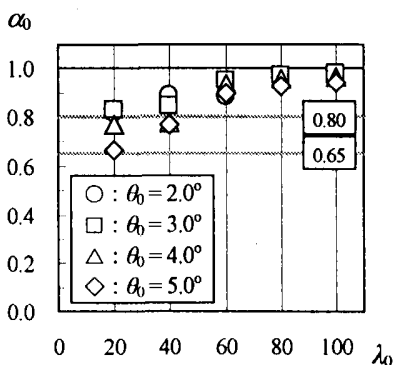

(2)ピン支持された円筒ラチス シェル ${ }^{14}$
図 9 FEM 弾性座屈荷重の FEM 線形座屈荷重に対する比 $\alpha_{0}$

\subsection{3 斜め材の断面算定に用いる座屈応力度 $\sigma_{\text {ord }}$ の計算}

I. 図5に示されるような母線縁上の節点をピン支持された円筒ラチスシ エルが，等分布鉛直荷重 $P_{10}(=9.8 \mathrm{kN})$ を受ける場合について, FEM 線 形弾性解析を行い，部材 $i$ の軸力 $N_{v i}$ を求める. 圧縮軸力を生じる斜め材 の中で, $N_{w i} / N_{p i}$ が最大となる部材を特定部材とする. 特定部材に関して, 軸力およひ断面積を，各々， $N_{v}$ および $A_{v}$ とする.

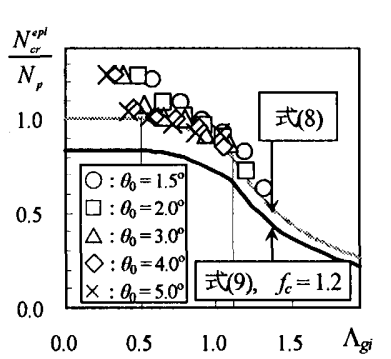

(1)軸圧縮される円筒ラチス シェル ${ }^{15)}$

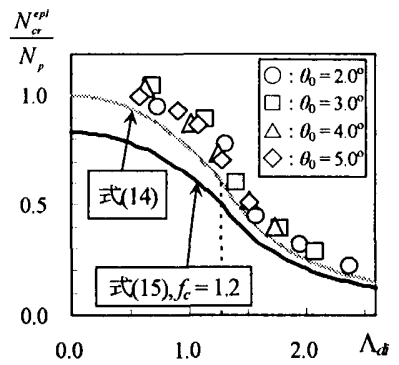

(2)ピン支持された円筒ラチス シエル ${ }^{14)}$
図 10 特定部材の正規化細長比と弾塑性座屈軸力の関俰

II. 次式を解いて最小の線形座屈固有值 $\lambda_{\text {cond }}^{\text {hin }}$ を求める.

$$
\operatorname{det}\left|\left[\mathbf{K}_{\mathbf{E}}\right]+\lambda_{\text {cri }}^{\text {lin }}\left[\mathbf{K}_{\mathbf{G}}\left(N_{v i}\right)\right]\right|=0
$$

次式により斜め材の線形座屈応力度 $\sigma_{c n d}^{\text {lin }}$ を計算する.

$$
\sigma_{\text {crd }}^{\text {lin }}=\left(\lambda_{\text {cnd }}^{\operatorname{lin}} N_{v}\right) / A_{v}
$$

III. 斜め材の弾性座屆応力度 $\sigma_{c n d}^{\text {ela }}$ を次式により計算する.

$$
\sigma_{c r d}^{\text {ela }}=\alpha_{d} \sigma_{c \text { ch }}^{\text {lin }}
$$

IV. 斜め材の部材断面算定に用いる弾塑性座屈応力度の計算

(i) 次式により正規化細長比 $\Lambda_{d}$ を計算する.

$$
\Lambda_{d i}=\sqrt{\frac{\sigma_{p}}{\sigma_{c r d}^{e l a}}}
$$

(ii) 図 10(2)は特定部材の正規化細長比と弾塑性座屈軸力 $N_{a r}^{e p l}$ の関倸 ${ }^{14)}$ を 示す. なお， $\Lambda_{d i}$ は式(13)により計算され，かつ， $\alpha_{d}$ として式(3)を用いて いる. また, $N_{c r}^{e p l}=\left(P_{\sigma}^{e p l} / P_{v 0}\right) N_{v}$ として計算されている. 図 10(2)を参照 し， 弾塑性座屈応力度の推定值 $\sigma_{\text {crti }}^{E d}$ を計算する.

$$
\left.\begin{array}{ll}
\sigma_{c t d i}^{E s t}=\sigma_{p}\left(1-0.24 \Lambda_{d i}{ }^{2}\right) & \left(\Lambda_{d i}<1 / \sqrt{0.6}\right) \\
\sigma_{c t i t}^{E s t}=\sigma_{p} / \Lambda_{d i}{ }^{2} & \left(\Lambda_{d i} \geq 1 / \sqrt{0.6}\right)
\end{array}\right\}
$$

(ii) 部材断面算定に用いる弾塑性座屈応力度 $\sigma_{c n \text { b }}$ を計算する.

$$
\sigma_{\text {crdi }}=\sigma_{\text {crd }}^{E \text { id }} / f_{c}
$$

ただし, $f_{c}=1.2$ とする.

\section{2 断面修正係数 $f_{i}$ の計算}

I. 日本建筑学会鋼構造限界状態設計指針・同解説 ${ }^{19}$ にみられる軸力と曲 げを受ける部材の設計式を援用し，次式を満たすように断面修正係数 $f_{1 i}$ を定める.

$$
\frac{N_{d}}{f_{1 i} N_{p i}}+0.85 \frac{M_{d}}{f_{1 i} M_{p i}}=1
$$

なお, $N_{d b}$ と $M_{d}$ は断面算定用部材力であり,その算出法は図 8 を参照する. 上式を $f_{i i}$ について解くと次式を得る.

$$
f_{i i}=\left(N_{d i} M_{p i}+0.85 M_{d i} N_{p i}\right) /\left(N_{p i} M_{p i}\right)
$$

II. 圧縮材のみ，座屈照查も行う．次式を解き $f_{2}$ を求める。

$$
f_{2 i}=N_{d i} /\left(\sigma_{r i} A_{p r}\right)
$$

母線方向材について $\sigma_{\sigma r i}=\sigma_{c y i n}$, 斜め材について $\sigma_{\sigma r}=\sigma_{c n d}$ とする. 管厚修正係数 $f_{i}$ は $f_{1 i}$ と $f_{2 i}$ のうち, より大きな方とする. 全ての部材について次式が満たされた場合，断面が収束したと判断する.

$$
1-\delta \leqq f_{i} \leqq 1+\delta
$$

$\delta=0.05$ とする. また，収束計算の繰り返し回数上限は 20 とする.

2.3 断面算定用最小部材力の定義, 管径の修正など.

\subsection{1 断面算定用最小部材力係数 $\gamma$}

文献 10)において，円筒ラチスシェルの断面算定に用いる断面算定用最 小部材力係数 $\gamma$ の適切な值として $0.4 \sim 0.6$ という值が示されている. 本研 究では，この成果を踏まえ， $\gamma=0.6$ とする.

\subsection{2 断面算定用最小部材力 $N_{\min }, M_{\text {min }}$}

母線方向材と斜め材では, 座屈特性や忍力性状が異なるので, 先に示し たように，それぞれ，別個に断面算定に使用する弾塑性座屈応力度を仮定 した，そこで，断面算定用最小部材力 ${ }^{10)} N_{\text {min }}$ と $M_{\text {min }}$ についても，各々，母 線方向材と斜め材に対して個別に定義して，これを用いる.

\subsection{3 管径 $d_{i}$ の修正}

管厚 $t_{i}$ が管径 $d_{i}$ の $20 \%$ の值 $\left.{ }^{10}\right)$ よりも大きくなる状況では, 全部材につい て管径が不足しているものと見なして部材断面算定を打ち切り, 初期仮定 断面の部材細長比 $\lambda_{0}$ を 10 だけ小さくして部材断面算定をやり直すことと した. 修正された部材細長比を用いても管径が不足する場合は，同様に部 材細長比をさらに 10 だけ小さくする.この手続きは断面が収束し，かつ， 
部材細長比の修正が行われなくなるまで繰り返される，ただし，部材細辰 比の修正は，斜め材と母線方向材に対して別々に行われる. 例えば, 具体 的には，母線方向材について管厚 $t_{i}$ が管径 $d_{i}$ の $20 \%$ 以上になったが斜め材 の管厚 $\boldsymbol{t}_{i}$ は管径 $d_{i}$ の $20 \%$ 末満である場合, 母線方向材の部材細長比を 10 だけ小さくし, かつ, 斜め材の部材細長比は変更せずに部材断面算定をや り直す. 一方，母線方向材の管厚 $t_{i}$ が管径 $d_{i}$ の $20 \%$ 未満であり，かつ, 斜 め材の管厚 $t_{i}$ が管径 $d_{i}$ の $20 \%$ の值よりも大きくなった場合，斜め材の部材 細長比のみを 10 だけ小さくして部材断面算定を再度実行する.

2.4 形状初期不整を考虑した部材断面算定

部材断面算定において, 形状初期不整の影響を考慮するにはいくつかの 方法が考えられる. 例えば, 三角形格子の単層ラチスドームを対象とした 文献 11)では, 等価シェル厚 $t_{e}$ の $20 \%$ 程度のたわみが 1 節点にのみ与えら れた場合において,ノックダウンファクターが 0.6 程度 ${ }^{17 て ゙ あ る こ と か ら ， ~}$ $\alpha_{0}=0.6$ として部材断面算定されたラチスドームは形状初期不整を考慮し た部材断面算定がなされたものとしている.つまり，形状初期不整の影響 を $\alpha_{0}$ に含めている. また，文献 12)では形状初期不整がないものとして断 面算定されたラチスドームに対して，その最大耐力が形状初期不整により どう低下するかを分析し，形状初期不整による最大耐力低减係数を定める ことが示唆されている.これらの方法は形状初期不整の影響を容易に考慮 できる長所を持つ.

一方で, 部材断面算定を行う際には部材力を計算するので, 形状初期不 整が与えられた場合の部材力を計算し，その部材力を用いて部材断面算定 を行うことも一つの方法と考えられる ${ }^{18)}$. 本報では， 3 番目の方法を採用 する. すなわち，(1) 完全形状のモデルに対して形状初期不整を与えるこ とにより節点座標値をずらしたモデルを作成し，(2) そのモデルと完全形 状のモデル双方について部材断面の算定を行い，(3) 双方のモデルの部材 断面を比較して，大きな方を採用する. なお，(4)この部材断面の取捨選 択は繰返し計算ステップごとに行われる。

\section{3. 断面算定法の検討のために用いる円筒ラチスシェルのモデル \\ 3.1 全体形状}

ラチスシェルの高さや曲率半径 $R$ を表す倸数として，図 1 に示されてい る部材半開角 $\theta_{0}$ を用いる. 本章では, $\theta_{0}=2.0^{\circ}, 3.0^{\circ}, 4.0^{\circ}$ および, $5.0^{\circ}$ の 4 種類とする. X 軸方向の長さ $L$ は母線方向材の長さ $\ell_{0}$ と母線方向部材数 $p$ の積として表される. ここでは $p=12$ ，かつ，部材長 $\ell_{0}=400 \mathrm{~cm}$ とするの で $L=48 \mathrm{~m}$ となる. 一方, 円弧方向長さ $B$ は，境界材の長さ $b$ と円弧方向 部材数 $n(=10)$ の積として表される. 母線方向材と斜め材の交角は 60 度, $b=346 \mathrm{~cm}$ とし, 従って, $B=34.6 \mathrm{~m}$ となる. また，母線方向辰 $L$ の円弧長 $B$ に対する比 $L / B$ は 1.4 である.

本報では, 上記の円筒ラチスシェルについて, (i) 形状初期不整を考虑せ ずに部材断面算定する場合と，(ii) 2.4 章で述べた方法に従い，形状初期不 整を考慮して部材断面算定する場合の両方を分析対象とする. なお, 形状 初期不整を考慮せずに部材断面算定されたラチスシェルをラチスシェル A, 形状初期不整を考慮して部材断面算定されたラチスシェルをラチスシェル B と呼ぶことにする.

\section{2 部材の初期仮定断面}

初期仮定断面の管厚 $t_{i}$ を $2.0 \mathrm{~cm}$ とする. また，初期仮定断面の部材細長 比は， $\lambda_{0}=20,40,60,80$ ，および 100 の 5 種類を採用する.

境界線（図 1 の節点 $\mathrm{C}_{1}, \mathrm{C}_{2}, \mathrm{C}_{4}, \mathrm{C}_{3}, \mathrm{C}_{1}$ を結ぶ線）の上にある部材を境 界材と呼ぶことにする. 境界材の部材断面は $\lambda_{0}=20$ および $t_{i}=2 \mathrm{~cm}$ とし，
かつこれらの値は部材断面算定を通じて変更されないものとするこれ は，境界材の早期の降伏を防ぐためである.

\section{3 荷重条件}

シェル表面の単位面積あたりの荷重を $p_{\text {urget }}=3.92 \mathrm{kN} / \mathrm{m}^{2}$ とする. 1 節点あ たりの荷重 $P_{\text {arget }}$ は次式(20)により計算されるむのとする ${ }^{10}$. 本法では $\ell_{0}=$ $400 \mathrm{~cm}$ なので, 式(20)によると $P_{\text {target }}=54.32[\mathrm{kN}]$ となる.

$$
P_{\text {target }}=\frac{\sqrt{3}}{2} \ell_{0}^{2} p_{\text {target }}
$$

本報では, 円筒ラチスシェルの最大耐力 $P_{a}$ が, 式(20)により求められる $P_{\text {tanget }}$ よりも大きくなるように部材断面を算定する.

\section{4 部材断面算定に用いる形状初期不整}

本報では，形状初期不整の例として，図 12 および式(21)に示されるよう な母線方向 1 半波かつ円弧方向 2 半波のモードを採用する.これは, 初期 仮定断面をもつ部材で構成された円筒ラチスシェルの固有モードが図 11 に例示されるように母線方向 1 半波かつ円弧方向 $3 \sim 4$ 半波程度のモードを 示したことと，文献2)を参考にして仮定したものである.

$$
\omega_{0}=\omega_{\max } \sin \frac{\pi x}{L} \sin \frac{2 \pi R \phi}{B}
$$

最大振幅量 $\omega_{\max }$ として, 母線方向長 $L$ の 500 分の 1 の值を採用する ${ }^{15}$. 本報では形状初期不整を上記のように仮定したが, 実際に発生する形状 初期不整は個々の設計例により異なると考えられ，従って，本来ならば， 個々の設計例の施工法や施工精度などを考慮して定められるべきである. 個々のラチスシェルに応じた形状初期不整の仮定の一般的方法は，本報の 議論の外としたい

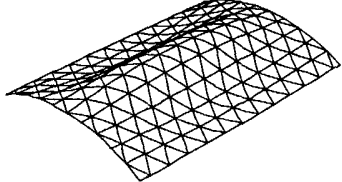

図 11 固有モードの例 $\left(\theta_{0}=3.0^{\circ}, \lambda_{0}=60\right)$

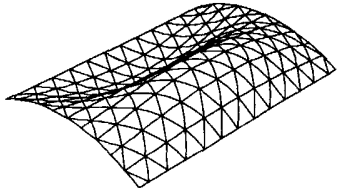

図 12 形状初期不整モード

\section{FEM 解析}

ラチスシェル B に関しては, (i) 形状初期不整を考慮しないFEM 解析と, (ii) 3.4 章で仮定した形状初期不整を考慮した FEM 解析を行う.一方, ラチ スシェル Aについては, 形状初期不整を考慮しない FEM 解析の夕行う.

\section{1 最大耐力 $P_{\boldsymbol{c}}$ の計算}

幾何非線形かつ材料非線形を仮定した増分解析 (以下, FEM 弾塑性座屈 解析）を行い，最大耐力 $P_{o r}$ を求める. $P_{c r}$ は図 10 節点 A に関する荷重一 変位曲線において，最初に見られた極大点に対応する荷重として定められ る. なお，FEM解析の詳細は文献 16)などを参照する.

FEM 弾塑性座屈解析に関して, 部材の降伏を考慮するために, 部材は図 13 に見られるように, 雨端を弾塑性ばねではさまれた弾性梁要素に2 分割 される. 弾塑性ばねは降伏後, 次式を満足するものとする.

$$
\left(\frac{N}{N_{p i}}\right)^{2}+\frac{M}{M_{p i}}=1
$$

ただし，Nはばねの軸力， $M$ は曲げモーメントである. 
なお，ラチスシェル A に関する結果と記号の右上に $A$ を, ラチスシェル $\mathrm{B}$ に関する結果は記号の右上に $B$ を，各々，付すことにする. 従って，ラ

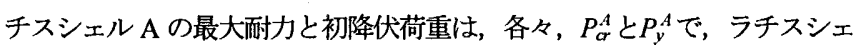
ル $\mathrm{B}$ の最大耐力と初降伏荷重は, 各々, $P_{\sigma}^{B}$ と $P_{y}^{B}$ で表される.

さらに，ラチスシェルBに関して，3.4 章で仮定した形状初期不整を考 慮して行われた FEM 解析により求められた最大耐力と初降伏荷重は，下 付添え字(ini)を添付され，各々， $P_{c(\text { (ini) }}^{B}$ と $P_{\text {(1in) }}^{B}$ で表される.

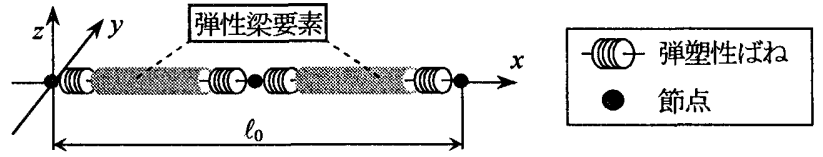

図 13 FEM 弾塑性座屈解析における部材モデル

\section{2 部材断面力の計算}

部材断面算定された円筒ラチスシェルに関して，荷重 $P_{\text {toger }}=54.32 \mathrm{kN}$ が 載荷されたときの部材断面力を分析するため, 幾何非線形材料線形の FEM 増分解析（以下，FEM 非線形弾性解析）を行う。なお，解析精度を保つた め，部材は2つの弾性梁要素に分割される (図 7 参照)。

表 1(1) ラチスシェルAの最大耐力一覧（形状初期不整がない場合）

\begin{tabular}{|c|c|c|c|c|c|c|}
\hline$\theta_{0}$ & & $\lambda_{0}=20$ & $\lambda_{0}=40$ & $\lambda_{0}=60$ & $\lambda_{0}=80$ & $\lambda_{0}=100$ \\
\hline \multirow{2}{*}{$2.0^{\circ}$} & $P_{y}^{A}[\mathrm{kN}]$ & $58.14(\mathrm{~A}-1)$ & $57.08(\mathrm{~A}-2)$ & $57.35(\mathrm{~B}-2)$ & $57.78(\mathrm{~B}-2)$ & $57.96(\mathrm{~B}-2)$ \\
\cline { 2 - 7 } & $P_{\sigma}^{A}[\mathrm{kN}]$ & 71.93 & 62.74 & 60.62 & 59.69 & 59.56 \\
\hline \multirow{3}{*}{$3.0^{\circ}$} & $P_{y}^{A}[\mathrm{kN}]$ & $65.18(\mathrm{~A}-1)$ & $61.60(\mathrm{~B}-2)$ & $61.58(\mathrm{~B}-2)$ & $61.77(\mathrm{C}-2)$ & $61.92(\mathrm{C}-2)$ \\
\cline { 2 - 7 } & $P_{\sigma}^{A}[\mathrm{kN}]$ & 80.11 & 66.51 & 64.14 & 63.31 & 62.96 \\
\hline \multirow{2}{*}{$4.0^{\circ}$} & $P_{y}^{A}[\mathrm{kN}]$ & $67.47(\mathrm{H}-1)$ & $60.45(\mathrm{E}-1)$ & $63.80(\mathrm{~F}-2)$ & $64.17(\mathrm{~F}-2)$ & $64.66(\mathrm{~F}-2)$ \\
\cline { 2 - 7 } & $P_{\sigma}^{A}[\mathrm{kN}]$ & 84.33 & 65.03 & 65.71 & 65.11 & 65.35 \\
\hline \multirow{2}{*}{$5.0^{\circ}$} & $P_{y}^{A}[\mathrm{kN}]$ & $68.17(\mathrm{H}-1)$ & $63.33(\mathrm{G}-2)$ & $63.94(\mathrm{G}-2)$ & $64.13(\mathrm{~F}-2)$ & $64.46(\mathrm{~F}-2)$ \\
\cline { 2 - 7 } & $P_{\sigma}^{A}[\mathrm{kN}]$ & 87.14 & 67.60 & 66.44 & 66.02 & 65.95 \\
\hline
\end{tabular}

表 1(2) ラチスシェルB の最大耐力一覧

(3.4 章の形状初期不整を考慮した FEM 弾塑性座屈解析結果)

\begin{tabular}{|c|c|c|c|c|c|c|}
\hline$\theta_{0}$ & & $\lambda_{0}=20$ & $\lambda_{0}=40$ & $\lambda_{0}=60$ & $\lambda_{0}=80$ & $\lambda_{0}=100$ \\
\hline \multirow{2}{*}{2.0} & $P_{y \text { (in) }}^{\beta}[\mathrm{kN}]$ & 56.99(A-1) & $5.25(\mathrm{~A}-2)$ & 55.13(B-2) & $55.54(\mathrm{~B}-2)$ & 55.70(B-2 \\
\hline & $P_{c \text { (fin })}^{B}[\mathrm{kN}]$ & 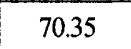 & . & . & 1.00 & 57.22 \\
\hline \multirow{2}{*}{$3.0^{\circ}$} & $P_{\text {(nii) }}^{B}[\mathrm{kN}]$ & 63.43(H & $58.34(\mathrm{D}-2)$ & 58.14(I & $58.31(\mathrm{D}-2)$ & $58.41(\mathrm{D}$ \\
\hline & $P_{c(\text { iin })}^{B}[\mathrm{k}$ & 78.69 & 65.5 & 62.66 & 61.06 & 60.42 \\
\hline \multirow{2}{*}{$4.0^{\circ}$} & $P_{\mathcal{y}(\mathrm{mi})}^{B}[\mathrm{kN}]$ & 65.30 & 9.97 & 57.92 & $58.02(\mathrm{~F}-2)$ & $58.32(\mathrm{I}$ \\
\hline & $P_{\sigma \text { (ini) }}^{B}[\mathrm{kN}]$ & 83.06 & 67.65 & 61.89 & 60.36 & 59.63 \\
\hline \multirow{2}{*}{$5.0^{\circ}$} & $P_{y \text { (ini) }}^{B}[\mathrm{kN}]$ & $66.07(\mathrm{H}$ & $59.21(\mathrm{~F}-2)$ & $58.06(\mathrm{~F}-2)$ & $58.08(\mathrm{~F}-2)$ & $57.73(\mathrm{~F}-$ \\
\hline & $P_{c(\text { ini })}^{B}[\mathrm{kN}]$ & 85.31 & 66.21 & 61.98 & 60.52 & 58.53 \\
\hline
\end{tabular}

\section{FEM解析結果}

\section{1 最大耐力 $\boldsymbol{P}_{\boldsymbol{c}}$ と初降伏荷重 $\boldsymbol{P}_{\nu}$}

最大耐力 $P_{\sigma}$ と初降伏荷重 $P_{y}$ の一覧を表 1 に示寸.表 1 の(1)は $P_{a r}^{A}$ と $P_{y}^{A}$ の

一覧である. 一方，表 $1 の(2)$ は $P_{\text {o(ini })}^{B} と P_{\text {y(iii) }}^{B}$ の一覧である.

アルファベットは最初に降伏した部材を意味しており, 図 14 を参照する. なお，最初に降伏した部材を，初降伏部材と呼ぶことにする．さらに，ア ルファベットの後ろについている数字が 1 である場合, 初降伏部材の断面 が軸力と曲げの相関（式(17)）により定まったことを意味する. 一方，こ
の数字が 2 ならば初降伏部材の断面は座屈の照査（式(18)）により定まっ ている. 従って, 例えば, A-1 と記されたケースでは, 初降伏部材は図 14 の部材 A であり，かつ，その部材の断面は軸力と曲げの相関式に基づき定 められていると判断する.

表 1 によれば， $\lambda_{0}$ が 40 以上ならば，母線方向材が最初に降伏し，かつ， 初降伏部材は座届の照査により定まる傾向にあることが確認される.
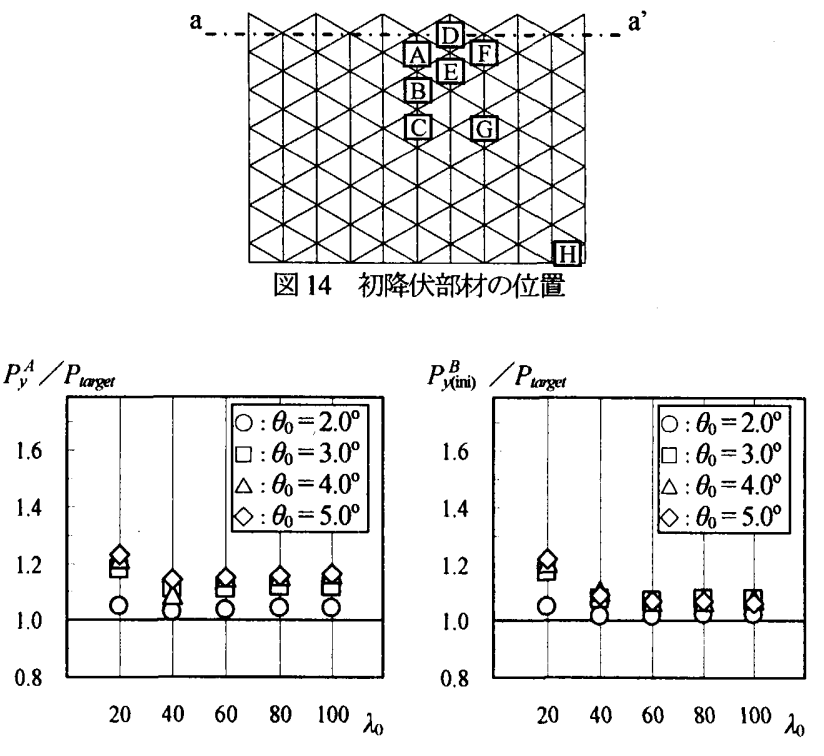

(1) ラチスシェルA

(2)ラチスシェルB

(形状初期不整を考虑した FEM 解析結果)

図 15 初降伏荷重 $P_{y}$ の目標荷重 $P_{\text {Lagyer }}$ に対する比

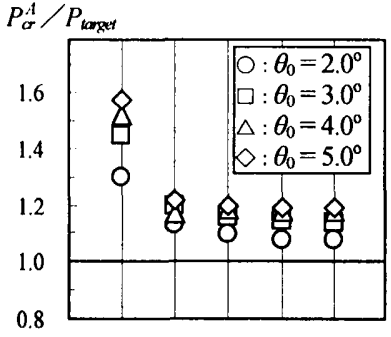

$\begin{array}{llllll}20 & 40 & 60 & 80 & 100 & \lambda_{0}\end{array}$ (1) ラチスシェルA

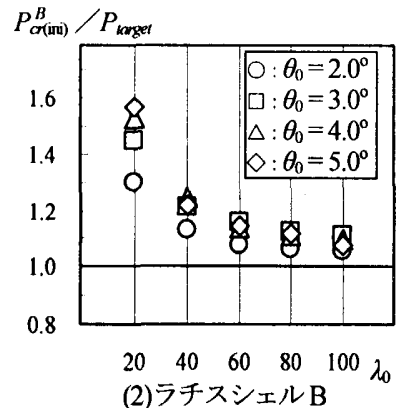

(形状初期不整を考慮した FEM 解析結果)
図 16 最大耐力 $P_{c r}$ の目標荷重 $P_{\text {larger }}$ に対する比

図 15(1)はラチスシェル A の初降伏荷重 $P_{y}^{A}$ の目標荷重 $P_{\text {targed }}(=54.32 \mathrm{kN})$ に対する比を, 図 15(2)はラチスシェル B の初降伏荷重 $P_{\text {(xini) }}^{B}$ の $P_{\text {turget }}$ に対す る比を, 各々, プロットしたグラフである. それぞれ, 横軸は部材細長比 $\lambda_{0}$ であり， 3.2 章に示される值である. ラチスシェル A とラチスシェル B ともに初降伏荷重は目標荷重 $P_{\text {kaget }}$ を上回ることが確認できる.

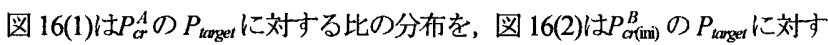
る比の分布を，それぞれ表している. 全てのケースについて，最大耐力は $P_{\text {taget }}$ に近く，かつこれを上回っている.

以上の結果より，全ての部材について，ほぼ啇切な断面が与えられてい ると言える.

\subsection{3 .4 章で仮定した形状初期不整が最大耐力に与える影響}

図 17(1)は $P_{y}^{B}$ に対する $P_{y \text { (ini) }}^{B}$ の低下の割合を，図 17(2)は $P_{c r}^{B} に$ 対する $P_{c(\text { ini) }}^{B}$ の低下の割合を，それぞれ，示している。 
$\theta_{0}$ が $3.0^{\circ}$ 以下であるラチスシェルに関して, $P_{y(\text { (iin) }}^{B}$ と $P_{c(\text { (ini) }}^{B}$ は, 各々, $P_{y}^{B}$ と $P_{c r}^{B}$ に対して $5 \%$ 程度低めである. 一方, $\theta_{0}$ が $4.0^{\circ}$ 以上であり，かつ， $\lambda_{0}$ が 60 以上であるラチスシェル B では $\left.P_{y(\text { in) }}^{B}\right) と P_{c(\text { ini) }}^{B}$ は, 各々, $P_{y}^{B}$ と $P_{c}^{B} に$ 対し て 10〜15\%程度低めである.

以上の結果より，3.4 章で仮定した形状初期不整は， $\theta_{0}$ が小さく $2.0^{\circ}$ 程度 であるラチスシェルよりも， $\theta_{0}$ が $4.0^{\circ}$ 以上と比較的むくりの度合いが大き なラチスシェルに対してより大きな影響を及ぼすと言える.

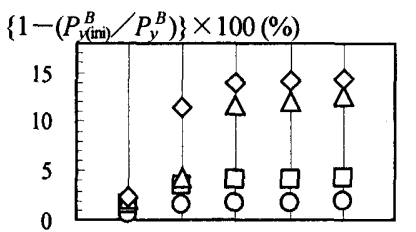

$\begin{array}{llllll}20 & 40 & 60 & 80 & 100 & \lambda_{0}\end{array}$

（1）初降伏荷重の低下

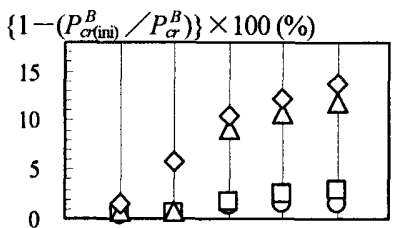

$\begin{array}{llllll}20 & 40 & 60 & 80 & 100 & \lambda_{0}\end{array}$

(2) 最大耐力の低下 $\bigcirc: \theta_{0}=2.0^{\circ}, \square: \theta_{0}=3.0^{\circ}, \triangle: \theta_{0}=4.0^{\circ}, \diamond: \theta_{0}=5.0^{\circ}$

図 17 形状初期不整の影響
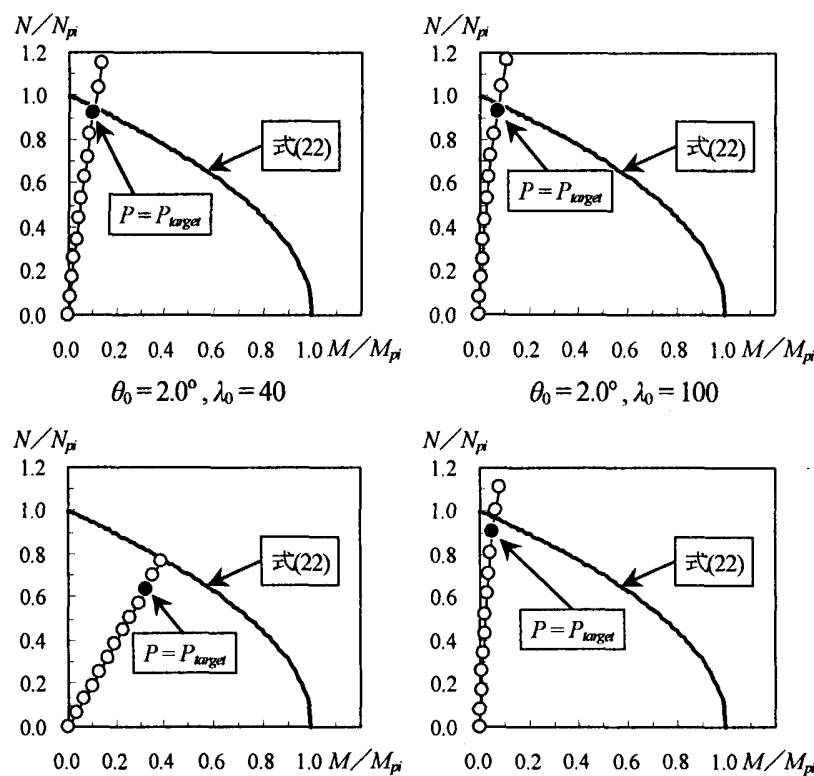

$\theta_{0}=5.0^{\circ}, \lambda_{0}=20$

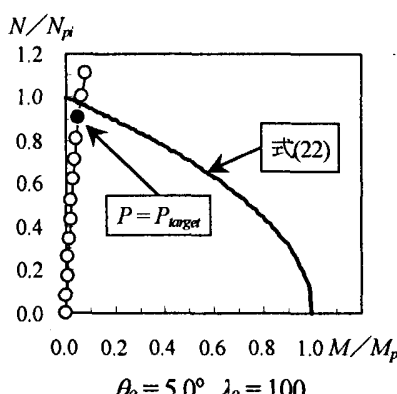

図 18 ラチスシェルBの初降伏部材の軸力 $N$ と曲げモーメント $M$ の関係

（FEM 解析において形状初期不整を考慮している）

5.3 ラチスシェル B の初降伏部材の軸力 $N$ と曲げモーメント $M$ の関係

図 18 は初降伏部材に関する軸力 $N$ と曲げモーメント $M$ の関係を示す.

これらの図は形状初期不整を考虑した FEM 非線形弾性解析に基づき描か れている. 黒塗りの点は荷重 $P$ が目標荷重 $P_{\text {taget }}$ と等しいことを意味する. 黒の太実線は式(22)を意味する，なお，紙面の都合により，ここには一部 のみ例として示し, その他については割愛した.

図 18 において, $\theta_{0}=5.0^{\circ}$ かつ $\lambda_{0}=20$ のラチスシェルにおいてのみ, 斜め 材が初降伏部材である. その他の母線方向材が初降伏部材であるケースで は曲げモーメント $M$ の発生は少なく，軸力 $N$ が卓越する.

\section{4 初降伏部材の断面算定用部材力 $N_{d}$}

初降伏部材について, $P=P_{\text {tagget }}$ の時の軸力 $N_{\text {ta }}$ に対する断面算定に用いた 軸力 $N_{d i}$ の精度を分析する. ラチスシェル A に関する結果は記号の右上に
$A$ を，ラチスシェル Bに関する結果は記号の右上に $B$ を，各々，付してい る.ささらにラチスシェル B に関して，3.4 で仮定した形状初期不整を考慮 して行われた FEM 解析結果には下付添字(ini)を付す.

図19(1)は $\left\{N_{t a}^{A} / N_{d i}^{A}-1\right\}$ 分布を, 図19(2)は\{ $\left.N_{t a(\mathrm{im})}^{B} / N_{d(\mathrm{im})}^{B}-1\right\} の$ 分布を, 各々, 表している. $\theta_{0}$ が $2.0^{\circ}$ のケースでは $N_{t a}^{A}$ は $N_{d b}^{A}$ に対して $10 \%$ 程度高め である.また, $\theta_{0}$ が $3.0^{\circ}$ のケースでは $N_{t a}^{A}$ は $N_{d i}^{A} に$ 対して $5 \%$ 程度高めである. $\theta_{0}$ が $4.0^{\circ}$ 以上ならば, $N_{t a}^{A}$ は $N_{d i}^{A}$ とほぼ一致する一方, $N_{t h(\mathrm{ini})}^{B}$ は $N_{d i(\mathrm{ini})}^{B}$ に対して 8\%程度大きめである.

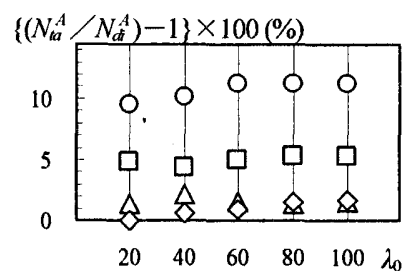

(1) ラチスシェルA

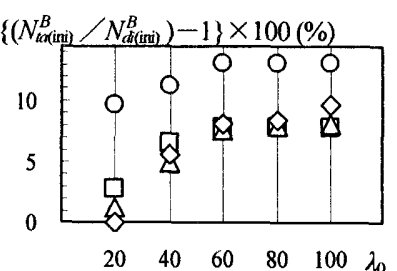

(2) ラチスシェルB
(形状初期不整を考慮した FEM 解析結果)

$\bigcirc: \theta_{0}=2.0^{\circ}, \square: \theta_{0}=3.0^{\circ}, \triangle: \theta_{0}=4.0^{\circ}, \diamond: \theta_{0}=5.0^{\circ}$

図 19 断面算定用部材力 $N_{d t}$ と軸力 $N_{t a}$ の比

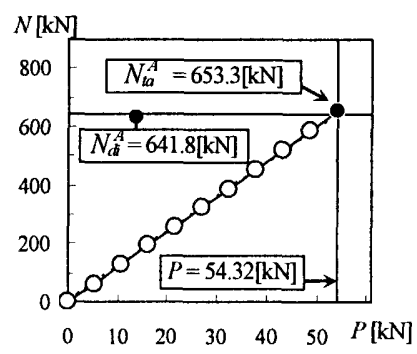

(1) ラチスシェル A

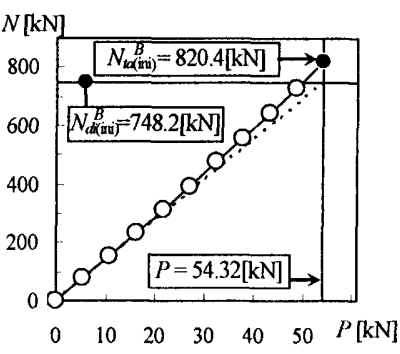

(2)ラチスシェル B
(形状初期不整を考慮した FEM 解析結果)

図 20 軸力 $N$ と荷重 $P$ の関係 $\left(\theta_{0}=5.0^{\circ}, \lambda_{0}=100\right)$

図20はFEM 非線形弾性解析結果に基づき得られた軸力 $N$ と荷重 $P$ の関 係である. 例として, $\theta_{0}=5.0^{\circ}$ かつ $\lambda_{0}=100$ のケースのみ揭載する.

ラチスシェルAでは, 軸力 $N$ が荷重に対して線形的に増加し, $N_{k t}^{A}$ と $N_{d b}^{A}$ が一致する. 一方, ラチスシェル Bでは, 荷重 $P$ に対して軸力 $N$ が非線形 的に増加する.この現象により, FEM 線形弾性解析に基づき得られた断面 算定用部材力 $N_{d(\text { (in) }}^{B}$ は $N_{t(\text { (tin) }}^{B}$ より小さくなる.

ところで，文献 4,5)を参照すれば， $\theta_{0}$ が小さいほど，座屈時の半波長は 長くなると思われる. 加えて, 座屈時の半波長と同じ長さの半波長を有す る形状初期不整が円筒ラチスシェルに強く影響する ${ }^{2)}$ と考えれば，本報で 仮定した母線方向 1 半波かつ円弧方向 2 半波の形状初期不整は 6 が $4.0^{\circ}$ 以 上のラチスシェルに強く影響寸るので, $\theta_{0}$ が $2.0^{\circ}$ 以下のラチスシェルには, 円弧方向半波数が 2 より小さな形状初期不整が強く影響寸ると考えられる. 以上の議論をまとめれば， $\theta_{0}$ が $2.0^{\circ}$ 以下であるような比較的扁平なラチ スシェルに円弧方向半波数が 2 より小さな形状初期不整が与えられた場合， 断面算定用部材力 $N_{d}$ の精度が相当悪くなるおそれがあり，注意が必要で ある.

\subsection{FEM 解析結果のまとめ}

本算定法により部材断面を算定された円筒ラチスシェルの最大耐力 $P_{\sigma}$ は, 形状初期不整（ただし，L/500）の有無に関係なく，設定した $P_{\text {lagee }}$ よ 
りも大きく，ほほ満足した值となっている.

さらに，初降伏部材が母線方向材であり，かつ，多くは座屈の照查によ り断面を定められたこと, 初降伏荷重 $P_{y}$ が $P_{\text {taget }}$ よりも大きめであったこ とを併せて考えると，母線方向に軸圧縮される円筒ラチスシェルの座屈性 状から定義された母線方向材の断面算定用の弾塑性座屈軸力が，母線方向 材の座届の照查において有用性を持ち，かつ，母線方向材に対して妥当な 部材断面を与えたと考えられる.

一方で, 形状初期不整を考慮した FEM 非線形弾性解析により, 荷重 $P=$ $P_{\text {araget }}$ の時の部材軸力は断面算定用部材力 $N_{d i}$ よりもわずかであるが小さく なることを確認した. これは, 荷重 $P$ に対して軸力が非線形的に増加する ためである. 特に $\theta_{0}$ が小さく $2.0^{\circ}$ 以下であるような円筒ラチスシェルに対 して, 円弧方向半波数が 2 より小さいような形状初期不整が仮定される場 合, 式(9)と式(15)の安全率 $f_{c}$ を 1.2 より大きくするなどの工夫が必要であろ 5.

\section{6. まとめ}

本報では円筒ラチスシェルが屋根架構として用いられる場合を対象とし て部材断面算定法を提示し，その有効性を検討した。

(i) 円弧長よりも母線長の長い円筒ラチスシェルが鉛直等分布荷重を受け る場合, 斜め材のみならず母線方向材にも大きな軸力が発生する.よって, 部材断面を算定する際に，斜め材とともに母線方向材の座屈軸力を定義す る必要がある. 本研究では，斜め材と母線方向材のそれぞれについて，座 屈軸力を定義した.

(ii) 断面算定用の部材力の計算は FEM 線形弾性解析の值を基本とした. 軸 力については幾何非線形性の影響は少ないとし，解析結果をそのまま用い たが，曲げモーメントについては軸力を用いた増幅を行った。

(iii) 具体例として，円筒ラチスシェルが，1 節点当たり $54.32 \mathrm{kN}$ の鋁直下 向き荷重を受けると想定し, 部材断面算定を行った. FEM 弾塑性座屈解析 を実施し, 断面算定された当該構造に関して, 最大耐力と初降伏荷重が, ともに54.32[kN]をほほ適切に満足することを確認した.これらの結果より， 本算定法により妥当な部材断面が算定できると確認した. ただし，本報で は分析の対象としていないが, 部材半開角が $2.0^{\circ}$ 以下のラチスシェルにつ いて円弧方向半波数が 2 より小さい形状初期不整が与えられた場合, 部材 の弾塑性座屈軸力をより小さく見積もるなどの工夫が必要であると考えら れる.

(iv) 上記のような問題はあるものの, 理論の容易さ, および, 妥当な部材 断面を算定できる点を踏まえれば，本算定法は，実設計の初期段階におけ る部材断面算定の有力な手段になり得ると期待される.

今後, 本研究で想定した以外の形状初期不整がある場合, 荷重分布が均一 でない場合の部材断面算定に関して分析を行い，本算定法の実用化に向け た分析を行う予定である.

\section{<謝辞>}

本報をまとめるにあたり，豊橋技術科学大学建設工学系助教授山田聖志 博士に有益な御助言をいただきました. 御礼申しあげます.

また, 本研究の一部は平成 15 年度, 日本学術振興会科学研究費補助金・ 基盤研究(C) 2 (課題番号 14550565, 代表者 : 加藤史郎) の助成により行 われました.
<参考文献>

1) 加藤史郎, 飯田稔，山下哲郎 : 等分布鉛直荷重を受ける周辺単純支持された単層 ラチス屋根の座屈荷重 : 構造工学論文集, Vol.41B,pp.247-257, 1995.3

2）山田聖志，田口孝：単層屋根型円筒ラチス構造の積雪時の弾性座屈性状 : 日本雪 工学会誌, Vol.11, No.4, pp.11-22, 1991.11

3) 粉川改 : 任意母線縁境界を持つ円筒網目ラチス屋根の全体座屈解析 一その 1 一様外玨下における非線形基礎式の数值解析法) : 日本建築学会論文報告集, 280 号, pp.53-65, 1979.6

4) 粉川孜 : 任意母線緑境界を持つ円筒網目ラチス屋根の全体座屈解析 一その2 一様外任下における座屈性状):日本建築学会論文報告集, 283 号, pp.76-86, 1979.9

5) 粉川孜 : 任意母線縁境界を持つ円筒網目ラチス屋根の全体座屈解析 一その3 不完全系の座屈性状）：日本建築学会論文報告集, 第 295 号, pp.53-65, 1980.9

6) 藤本益美 : 屋根型円筒ラチスシェル構造の解析・設計（3.6 座屈性状に及ぼすメ ッシュパターンの影響) : 日本建築学会空間骨組構造小委員会屋根型円筒ラチスシェ 儿構造作業委員会編, 1995.12

7) 陳沛山, 川口蒚 : スペース・フレームの最大座屈荷重形態 : 日本建築学会構造系 論文集, 第489号, pp.41-pp46, 1996.11

8）大森博司, 山本憲司 : 忘力分布を目的関数とする空間構造の形状最適化に関する 研究 一その2 スペースフレームへの適用一: 日本建築学会構造系論文集, 503 号, pp.77-pp83, 1998.1

9) 小河利行, 大崎純, 立石理恵 : 線形座屈荷重最大化と部材長一様化を目的とした 単層ラチスシェルの形状最適化: 日本建築学会構造系論文集, 570 号, pp.129-ppl36, 2003.8

10）加藤史郎, 高島英幸, 松永靖二 : 弾性 2 次解析を用いた単層ラチスシェルの断面 算定法についての一考察 : 日本建築学会構造系論文集, 511 号, pp.109-116, 1998.9

11) 加藤史郎, 松永靖二, 仁保裕 : 弾性二次解析を用いた単層ラチスドームの断面算 定法についての一考察，日本建築学会構造系論文集，No.526, pp93-100, 1999.12

12）加藤史郎, 金鍾敏 : 単層ラチスドームの座屈忘力度に関する分析と断面算定への 応用一等分布と偏載荷重を考虑して断面算定された周辺ローラー支持への場合一, 銵構造論文集，第 9 巻第 33 号, pp.49-64, 2002.3

13) Kato S., Kim J.M. and Cheong M.C.: A new proportioning method for member sections of single layer reticulated domes subjected to uniform and non-uniform loads: Engineering Structures, 25 (2003), pp. 1265 - pp. 1278, 2003, August.

14) 加藤史郎, 饭田稳, 南林注二, 武藤至 : 等分布鉛直荷重を受什る周边ピン支持さ れた単層円筒ラチス屋根の座屈荷重 : 第 12 回日本雪工学大会梗概集, pp,147-154, 1996.1

15）加藤史郎，仁保裕，金鍾敏 : 軸圧樎される直交異方性円筒ラチスシェルの弾塑性 座屈举動：日本建築学会構造系論文集, 2003.11

16)植木隆司, 加藤史郎, 向山洋一, 松栄泰男 : 両端に回転ばねのある部材で構成さ れる単層ラチスドームの弾塑性座屈荷重, 日本建築学会構造系論文報告集, No.448, pp47-58, 1993.6

17) 柴田良一，加藤史郎，植木隆志: きわめて扁平な阙接合ラチスドームの弾塑性座 屈荷重 等分布荷重を受ける周辺ピン支持 6 角形ドームの座屈応力度曲線につい て : 日本建築学会構造系論文報告集, 449 号, pp.143-153，1993.7

18）山下哲郎，加藤史郎：曲げを受ける柱の終局耐力式を用いた単層 2 方向格子シェ ルの断面設計 : 日本建築学会構造系論文集, 564 号, pp.87-194, 2003.3

19）銚構造限界状態設計指針・同解説：日本建築学会, 2002.9

20) 加藤史郎，仁保裕，金鍾敏: 軸王縮荷重を受ける部分円筒ラチスシェルの座屈軸 力に関する研究，日本建築学会構造系論文集, No.564, pp79-86, 2003.2

<注翻>

1) 文献 10)では設計用断面力と呼ばれる. 設計という言葉を用いた場合, 本章で示し たような固定荷重に対する断面算定のみならず，耐叕や耐風についても配慮し，か つ，接合部などのディデールまでをも含めて決定するものと捉えられる可能性があ る. 本報では固定荷重比例型の等分布荷重を想定した断面算定を行っているのみで あり，従って．用語からなるべく設計という言葉を排除することとした.

2) 文献 10)では設計用最小断面力と呼ばれる. 名称を変更した理由は注釈 1)と同じで ある.

(2004年1月23日原稿受理，2004年10月20日操用決定） 